README for:

\title{
DIGITAL GEOLOGIC MAP OF THE BUTLER PEAK 7.5' QUADRANGLE, SAN BERNARDINO COUNTY, CALIFORNIA
}

\author{
By Fred K. Miller ${ }^{1}$, Jonathan C. Matti ${ }^{2}$, and Howard J. Brown \\ Digital preparation by P.M. Cossette ${ }^{1}$
}

Open-File Report OF 00-145

Version 1.0

2000

Prepared in cooperation with:

U.S. Forest Service, San Bernardino National Forest

California Division of Mines and Geology

This report is preliminary and has not been reviewed for conformity with U. S. Geological Survey editorial standards. Any use of trade, product, or firm names is for descriptive purposes only and does not imply endorsement by the U. S. Government.

This database, identified as "Digital geologic map of the Butler Peak 7.5' quadrangle, San Bernardino County, California" has been approved for release and publication by the Director of the USGS. Although this database has been reviewed and is substantially complete, the USGS reserves the right to revise the data pursuant to further analysis and review. This database is released on condition that neither the USGS nor the U. S. Government may be held liable for any damages resulting from its use.

U.S. Geological Survey

1 W904, Riverside Avenue, Spokane, WA 99201-1087

2520 N Park Avenue, Tucson, AZ 85719

3 Pluess-Staufer (California), Inc., P.O. Box 825, Lucerne Valley, CA 92356 


\title{
TABLE OF CONTENTS
}

\author{
Introduction \\ How to obtain paper plots \\ Database contents \\ Data package \\ Plot package \\ Other files \\ Software utilities \\ How to obtain the digital files \\ How to extract the geologic map database from the tar file \\ Digital database \\ PostScript plot file \\ Portable document format (.pdf) files \\ How to convert the ARC/INFO export files \\ Digital geologic map specifications \\ Digital compilation \\ Base map \\ Spatial resolution \\ Map accuracy standards \\ Faults and landslides \\ Database specifics \\ General \\ Lines \\ Polygons \\ Points \\ References
}

\section{INTRODUCTION}

Open-File Report 00-145, is a digital geologic map database of the Butler Peak 7.5' quadrangle that includes (1) ARC/INFO (Environmental Systems Research Institute, http://www.esri.com) version 7.2.1 Patch 1 coverages, and associated tables, (2) a Portable Document Format (.pdf) file of the Description of Map Units, Correlation of Map Units chart, and an explanation of symbols used on the map, btlrpk_dcmu.pdf, (3) a Portable Document Format file of this Readme, btlrpk_rme.pdf (the Readme is also included as an ascii file in the data package), and (4) a PostScript plot file of the map, Correlation of Map Units, and Description of Map Units on a single sheet, btlrpk.ps. No paper map is included in the Open-File report, but the PostScript plot file (number 4 above) can be used to produce one. The PostScript plot file generates a map, peripheral text, and diagrams in the editorial format of USGS Miscellaneous Investigation Series (Map I-series) maps. This README file describes the digital data, such as types and general contents of files comprising the database. Information is also provided on how to both extract and plot the map. Metadata information can be accessed at http://geonsdi.er.usgs.gov/cgi-bin/publication?open-file. 
Within the geologic map database, map units are identified by standard geologic map criteria such as formation-name, age, and lithology. Even though this is an authorprepared report, every attempt has been made to closely adhere to the stratigraphic nomenclature of the U. S. Geological Survey. Descriptions of the units and geologic map information are coded into polygon, arc, and point tables (.pat, .aat, and .pat, respectively). Detailed information and descriptions of units can be obtained from the Description of Map Units accessible by plotting either the PostScript file of the geologic map or the .pdf file.

\section{HOW TO OBTAIN PAPER PLOTS}

To obtain paper plots of the geologic map and accompanying text, download the plot package listed below.

\section{DATABASE CONTENTS}

The files constituting the geologic map database of this Open-File Report are listed below along with the interchange files from which they are extracted.

\section{Data Package}

All files listed below are in a compressed tar file named btlrpk.tar.gz (3 MB); see section below titled, SOFTWARE UTILITIES.

\begin{tabular}{|c|c|c|}
\hline $\begin{array}{l}\text { ARC/INFO } \\
\text { interchange files }\end{array}$ & $\begin{array}{l}\text { Butler Peak } \\
\underline{\text { coverages }}\end{array}$ & Contains \\
\hline btlrpk_geo.e00 & btlrpk_geo & $\begin{array}{l}\text { Contacts, faults, and geologic unit } \\
\text { labels as annotation in annotation } \\
\text { subclass, anno.geo }\end{array}$ \\
\hline btlrpk_ldr.e00 & btlrpk_ldr & Annotation leaders \\
\hline btlrpk_pts.e00 & btlrpk_pts & $\begin{array}{l}\text { Attitudes and their dip values. Dip } \\
\text { values plotted as annotation. }\end{array}$ \\
\hline lines.rel.e00 & lines.rel & $\begin{array}{l}\text { Line dictionary (Matti and others, } \\
\text { 1998b) }\end{array}$ \\
\hline points.rel.e00 & points.rel & $\begin{array}{l}\text { Point dictionary (Matti and others, } \\
\text { 1998c) }\end{array}$ \\
\hline
\end{tabular}

The directory, info/, is produced in the process of importing interchange files to ARC coverages in ARC/INFO. The Butler Peak info/ directory contains:

$\underline{\text { Feature Attribute tables }}$

Polygon attribute table

Arc attribute tables

btlrpk_geo.pat

Point attribute tables

btlrpk_geo.aat, btlrpk_ldr.aat

btlrpk_pts.pat 


\section{Additional tables $^{*}$}

lines.rel

Dictionary, contains all SCAMP line codes (Matti and others, 1998b)

points.rel Dictionary, contains all SCAMP point codes (Matti and others, 1998c)

*These tables contain complete dictionary information for both lines and points.

\begin{tabular}{lll} 
Raster file & Resultant image & Contains \\
\cline { 2 - 3 } btlrpk.tif & Butler Peak & Topographic base from 500 \\
basemap & dpi scan of USGS Butler \\
& Peak 7.5' quadrangle, 1967: \\
& registered and rectified to the \\
& Butler Peak 7.5' quadrangle, in \\
& Geotiff format.
\end{tabular}

ASCII text files

Readme.txt Readme text (this file)

\section{Plot Package}

PostScript plot files of the geologic map and explanation (please see section below titled, SOFTWARE UTILITIES for additional information).
Compressed file
$\underline{\text { Resultant image }}$
$\underline{\text { Contains }}$
btlrpk.ps.gz
btlrpk.ps
PostScript plot file

The PostScript file is a compressed UNIX file requiring a gzip compatible program to uncompress it. Uncompressed, it will plot a 1:24,000 scale, full color geologic map of the Butler Peak quadrangle on the topographic base, including a Correlation of Map Units diagram, and the Description of Map Units. The plot is in the editorial format of the U.S. Geological Survey's Miscellaneous Investigation (Map I) map series, and is approximately $47 \times 33$ inches in size. The file has been successfully plotted on Hewlett-Packard large format plotters, models HP650C, HP755CM, and HP2500C.

\section{Other files}

Readme.pdf btlrpk_dcmu.pdf
PDF version of this document Description of Map Units, Correlation of Map Units, and symbols used 
btlrpk_met.txt

Federal Geographic Data Committee (FGDC) compliant metadata file derived from the geologic coverage, btlrpk_geo; plain text file.

The following interchange files of the respective symbol sets used to plot the full geologic map sheet:

$\begin{array}{ll}\text { geoSCAMP2.lin.e00 } & \text { Line set } \\ \text { geoSCAMP2.mrk.e00 } & \text { Points (marker set) } \\ \text { scamp2.shd.e00 } & \text { Colors (shade set) } \\ \text { geology2.shd.e00 } & \text { Patterns (shade set) }\end{array}$

\section{SOFTWARE UTILITIES}

Files which have the .gz file extension were compressed using gzip. Gzip utilities are available free of charge via the internet at the gzip home page, http://www.gzip.org

The data package is additionally bundled into a single tar (tape archive) file. The individual files must be extracted using a tar utility, available free of charge via the internet through links on the Common Internet File Formats page, http://www.matisse.net/files/formats.html. One such utility is WinZip, available at http://www.winzip.com (WinZip can also decompress files).

Files in the plot package have been prepared to produce optimum plots using the ARC/INFO compatible, SCAMP derived symbolsets listed below. These shade and marker sets are included in the btlrpk.ps.gz file, and are also available from the Southern California Areal Mapping Project (SCAMP) web site at http://wrgis.wr.usgs.gov/docs/ncgm/scamp/scamp.html At the above web site, click on 'Scamp GIS Activities'

$\begin{array}{ll}\text { geoSCAMP2.lin.e00 } & \text { Lines } \\ \text { geoSCAMP2.mrk.e00 } & \text { Points } \\ \text { scamp2.shd.e00 } & \text { Colors } \\ \text { geology2.shd.e00 } & \text { Patterns }\end{array}$

\section{HOW TO OBTAIN THE DIGITAL FILES}

The export files, and subsequently the data and plot files, constituting the geologic map database of this Miscellaneous Field Studies report may be obtained in several ways listed below:

1. The files can be obtained via the Web from Western Region Geologic Information Server. Go to the web page at http//wrgis.usgs.gov/openfile/of00-145 and follow the directions to download the files. 
2. The files can also be obtained by anonymous ftp over the Internet from wrgis.wr.usgs.gov. The files are located in the directory /pub/open-file/of00-145.

Note: .e00 files are best transferred using ascii mode

3. The U.S.G.S. will download requested data files onto user-submitted tapes/CDs.

\section{HOW TO EXTRACT THE GEOLOGIC MAP DATABASE FROM THE TAR FILE}

After downloading the files, they must be uncompressed using a gzip utility such as gzip itself or WinZip. The data files must then be extracted using the appropriate tar utility.

\section{Digital database}

$\underline{\text { To do this }}$

Uncompress btlrpk.tar.gz

to btlrpk.tar

Go to the directory that will hold the directory Butler Peak (if different from local_directory)

Extract the Butler Peak directory from the tar file
Type this at the Unix command prompt gzip -d btlrpk.tar.gz (or use gzip utility of choice)

cd local_directory

tar-xvbv \{path to tar file\}/btlrpk .tar (or use tar utility of choice)

This process will create a directory, btlrpk/, that contains the ARC/INFO interchange files and supporting files. The directory should contain the following files:

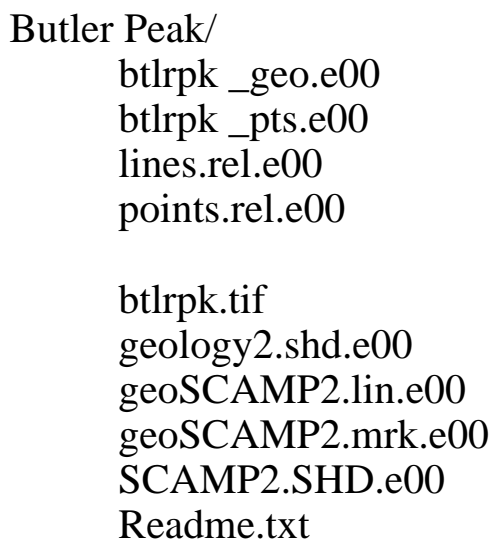

The following are not included in the database tar file, and are downloaded separately

btlrpk.ps.gz

Readme.pdf 
btlrpk_dcmu.pdf

btlrpk_met.txt

\section{PostScript plot file}

Uncompress a 17 MB uncompressed file, btlrpk.ps (full map) by typing gzip -d btlrpk.ps.gz (or use gzip utility of choice)

\section{Portable Document Format (.pdf) files}

.pdf files are not stored as gzip files. They are accessed using Adobe Acrobat Reader software, available free from the Adobe website http://www.adobe.com. Follow instructions at the website to download and install the software. Acrobat Reader contains an on-line manual and tutorial.

\section{HOW TO CONVERT THE ARC/INFO EXPORT FILES}

The ARC interchange (.e00) files are converted to ARC coverages using the ARC command IMPORT with the appropriate <option>.

Change directories to the btlrpk/ directory. From the ARC command line type: import <option> <interchange_file> <output>

e.g. import cover btlrpk_geo btlrpk_geo

ARC interchange files can also be read by some other Geographic Information Systems, including ArcView (ESRI) and MapInfo (http://www.mapinfo.com). Please consult your GIS documentation to see if you can use ARC interchange files and the procedure to import them.

\section{DIGITAL GEOLOGIC MAP SPECIFICATIONS}

\section{Digital compilation}

The geologic map information was scanned (initial raster scan in MS-DOS TIF format, 1200 dots per inch) from a base-stable original (scribeguide to clear-film, right-reading, 0.007 mil thickness, blackline positive) of the geologic map at 1:24,000 scale. The auto-vectorized, non-attributed scan was prepared by Optronics Specialty Company, Inc. and converted to an ARC coverage using the ARC command dxfarc $<$ input dxf file> <output map name>. Registration and transformation were subsequently completed. Lines, points, and polygons were edited using standard ARC/INFO commands. Digitizing and editing artifacts significant enough to display at a scale of 1:24,000 were corrected. 


\section{Base map}

The base map image (btlrpk.tif, Geotiff format) was prepared by scanning a scalestable clear film of the U.S Geological Survey, 1:24,000 Butler Peak 7. 5' quadrangle (1967) topographic map. Scanning was done using an Anatech Eagle 4080 monochrome 800 dpi scanner; at a resolution of 500 dpi. The raster scan was converted to a monochromatic image in ARC/INFO, and registered and rectified to the Butler Peak 7.5' quadrangle. No elements of the base layer are attributed. The base map is provided for reference only.

\section{Spatial resolution}

Use of this digital geologic map database should not violate the spatial resolution of the data. Although the digital form of the data removes the constraint imposed by the scale of a paper map, the detail and accuracy inherent in map scale are also present in the digital data. The fact that this database was edited at a scale of 1:24,000 means that higher resolution information is not generally present in the dataset. Plotting at scales larger than 1:24,000 will not yield greater real detail, although it may reveal fine-scale irregularities above the intended resolution of the database. Similarly, although higher resolution data is incorporated at some places, the resolution of the combined output will be limited by the lower resolution data.

\section{Map accuracy standards}

Until uniform National geologic map accuracy standards are developed and adopted, lines and points on SCAMP 1:24,000 scale geologic maps that are located to within 15 meters, relative to accurately located features on the base map, are considered to meet map accuracy standards. Dashed lines, indicated in the database coding as not meeting map accuracy standards, are generally located to within 30 meters, relative to accurately located features on the base map.

\section{Faults and landslides}

This database is sufficiently detailed to identify and characterize many actual and potential geologic hazards represented by faults and landslides, but it is not sufficiently detailed for site-specific determinations.

\section{Database specifics}

General-The map database consists of ARC/INFO format coverages which are stored in polyconic projection (Table 1), and a series of data tables. Digital tics define a 7.5 minute grid of latitude and longitude in the geologic coverages corresponding to the 7.5 minute tic grid on the topographic base map.

Table 1 - Map Projection 


$\begin{array}{ll}\text { Projection } & \text { Polyconic } \\ \text { Datum } & \text { NAD27 } \\ \text { Zunits } & \text { No } \\ \text { Units } & \text { Meters } \\ \text { Spheroid } & \text { Clark } 1866 \\ \text { X shift } & 0.0000000000 \\ \text { Y shift } & 0.0000000000 \\ \text { Parameters } & -117345.000 \text { longitude of central meridian } \\ & 34150.000 \text { latitude of projection's origin } \\ & 0.00000 \text { false easting (meters) } \\ & 0.00000 \text { false northing (meters) }\end{array}$

The content of the geologic database can be described in terms of feature classes that include lines, points, and areas (polygons) that compose the map. Definitions of the database items are explained in Table 2.

Table 2 - Item Definition Terms

ITEM NAME Name of the database field

WIDTH Maximum number of digits or characters stored

OUTPUT Output width

TYPE B-binary integer, F-binary floating point number, I-ASCII integer, C-ASCII character string

N. DEC. $\quad$ Number of decimal places maintained for floating point numbers

Lines-Lines are recorded as strings of arcs and are described in arc attribute (.aat) tables (Table 3). They define the boundaries of the map units, faults, the boundaries of open bodies of water, the map boundaries, and linear elements. These distinctions, including the geologic identities of the unit boundaries, are recorded in the L-TAG field according to the line types listed in Table 4. In addition, btlrpk_ldr contains lines that represent annotation leaders for unit labels. Btlrpk_ldr linear elements are attributed with only a single item, l-symb, in addition to the ARC/INFO assigned attributes.

Table 3 - Items Arc Attribute Table (btlrpk_geo.aat)

ITEM NAME WIDTH OUTPUT TYPE N. DEC

\begin{tabular}{|c|c|c|c|c|c|}
\hline FNODE\# & 4 & 5 & $\mathrm{~B}$ & & $\begin{array}{l}\text { internal node number, identifies the origin } \\
\text { of an arc (from-node) }\end{array}$ \\
\hline TNODE\# & 4 & 5 & $\mathrm{~B}$ & & $\begin{array}{l}\text { internal node number, identifies the end } \\
\text { of an arc (to-node) }\end{array}$ \\
\hline LPOLY\# & 4 & 5 & $\mathrm{~B}$ & & internal number, left polygon \\
\hline RPOLY\# & 4 & 5 & $\mathrm{~B}$ & & internal number, right polygon \\
\hline LENGTH & 8 & 18 & $\mathrm{~F}$ & 5 & length of arc in meters \\
\hline BTLRPK_GEO\# & 4 & 5 & $\mathrm{~B}$ & & internal arc number (value assigned by \\
\hline
\end{tabular}




\begin{tabular}{|c|c|c|c|c|}
\hline & & & & ARC/INFO) \\
\hline BTLRPK_GEO-ID & 4 & 5 & $\mathrm{~B}$ & user-ID (values assigned by the user) \\
\hline L-SYMB & 3 & 3 & $\mathrm{I}$ & $\begin{array}{l}\text { Line graphic. Calls line-type from line } \\
\text { set geoSCAMP2.lin }\end{array}$ \\
\hline L-TAG & 25 & 25 & $\mathrm{C}$ & $\begin{array}{l}\text { Line tag. Links line segments to their } \\
\text { definitions (in lines.rel) }\end{array}$ \\
\hline
\end{tabular}

Table 4 - Line Types Recorded in the L-TAG field (btlrpk_geo.aat) and an abbreviated summary of the corresponding parsed description in L-EXP in lines.rel

L-TAG

line tag

C17

C19

Contact, landslide, location meets map accuracy standard

standard

C29 Contact, sedimentary, location meets map accuracy standard

C30 Contact, sedimentary, location may not meet map accuracy standard

C31 Contact, sedimentary, inferred, location may not meet map accuracy standard

C49 Contact, igneous, location meets map accuracy standard

C50 Contact, igneous, location may not meet map accuracy standard

C51 Contact, igneous, inferred, location may not meet map accuracy standard

C59 Contact, igneous, gradational, location meets map accuracy standard

C67 Contact, metamorphic, inferred, location may not meet map accuracy standard

C70 Contact, metamorphic, inferred, location may not meet map accuracy standard

C75 Contact, metamorphic, gradational, observable, location meets map accuracy standard

CL1 Cartographic line, map boundary

F1 Fault, high angle, slip unspecified, generic, location meets map accuracy standard

F13 Fault, high angle, slip unspecified, inferred, location may not meet map accuracy standard

F19 Fault, high angle, slip unspecified, inferred beneath mapped covering unit, location may not meet map accuracy standard

F31 Fault, high angle, slip unspecified, generic, inferred, location may not meet map accuracy standard

F37 Fault, high angle, slip unspecified, generic, inferred beneath mapped covering unit, location may not meet map accuracy standard

F220 Fault, intruded, preintrusive existence inferred

FZ3 Fault zone boundary of cataclastic zone

LT2 Lineamant, aligned topographic saddles, located well but may not meet map accuracy standard 
Polygons-Geologic map units (polygons) are described in the polygon attribute table (Table 5). Map units are identified by the LABL item (Table 6). SCAMP geologic maps can be encoded with detailed, polygon-specific geologic information on a polygon-by-polygon basis, so that within a quadrangle, lateral variations in a particular map unit can be recorded in the map database. Polygons whose characteristics differ from the unit in general, are identified through the TAG item (Table 7), which allows variations that are unique to specific polygons to be described by adding letters to the map unit designation used in LABL. Polygons of each map unit for which the TAG item ends with the letter 'A' (eg, KbpA), are considered to be most typical of the map unit overall. Detailed encoding of polygons is not available on this version of the Butler Peak quadrangle, but the data-base is here set up so that encoding can be completed on the next version. For traditional descriptions of the map units, see the Portable Document Format file btlrpk_dmu.pdf, or a map generated from the PostScript plot file.

Table 5 - Items, Polygon Attribute Table (btlrpk_geo.pat)

\section{ITEM NAME WIDTH OUTPUT TYPE N. DEC}

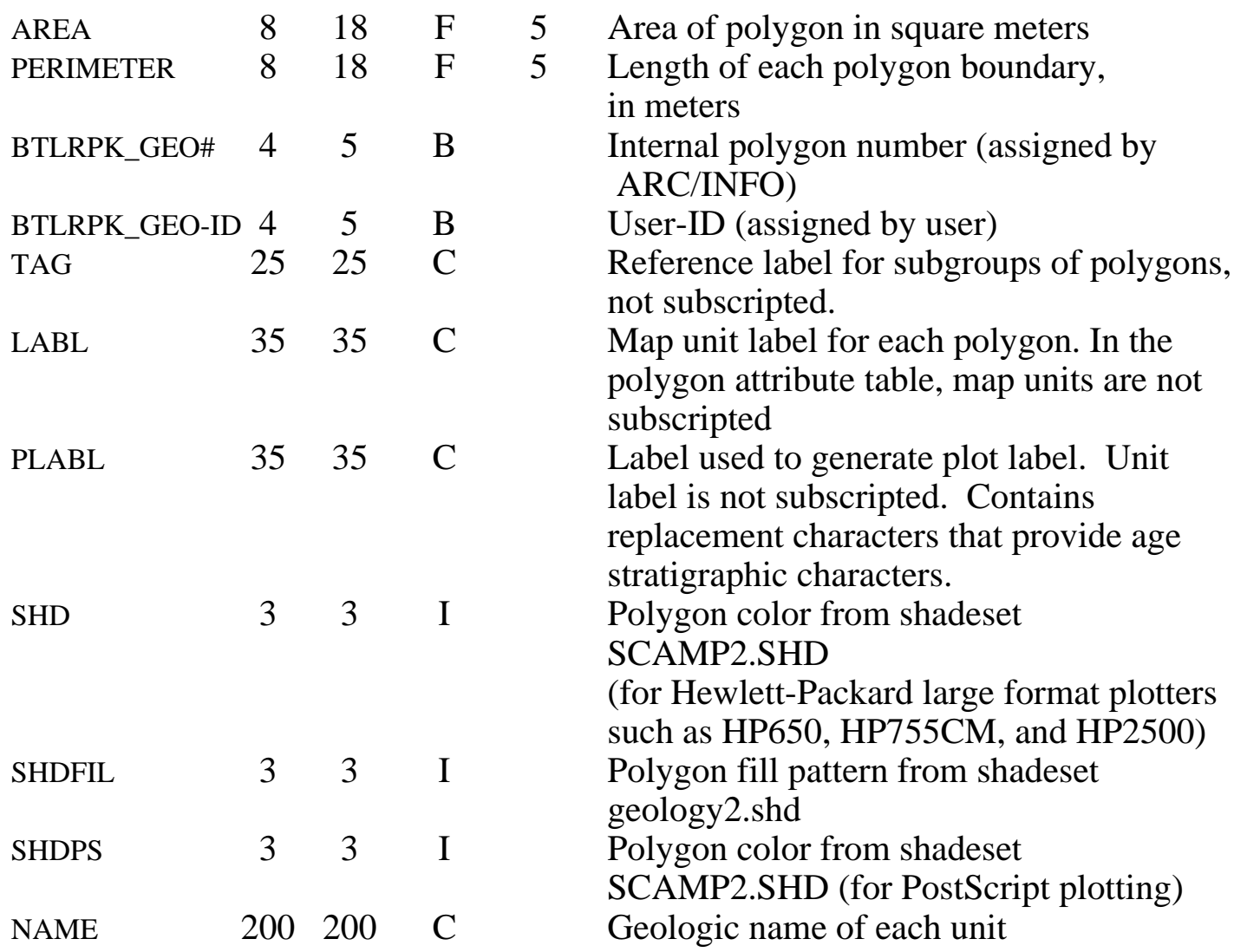

Table 6 - Map Units (LABL)

$\begin{array}{lllll}\text { Cbk } & \text { KJls } & \text { Krl } & \text { Qa } & \text { Qvof }_{1} \\ \text { Cc } & \text { KJos } & \text { Kwc } & \text { Qaf } & \text { Qvof }_{2}\end{array}$




$\begin{array}{lllll}\text { Cw } & \text { KJqd } & \text { Mm } & \text { Qc } & \text { Qvols } \\ \text { Cz } & \text { KJsp } & \text { Mzu } & \text { Qf } & \text { Qw } \\ \text { Ds } & \text { Kbp } & \text { PPbs } & \text { Qf }_{1} & \text { Qya } \\ \text { Jc } & \text { Kcm } & \text { Prcc } & \text { Qf }_{2} & \text { Qya } \\ \text { Jcr } & \text { Kcr } & \text { Prgsq } & \text { Qls } & \text { Qyc } \\ \text { Jd } & \text { Kdh } & \text { Prlsm } & \text { Qof } & \text { Qyf } \\ \text { Jrr } & \text { Kgm } & \text { Prqc } & \text { Qof } & \text { Qyf } \\ \text { Jsc } & \text { Kh } & \text { Prsc } & \text { Qols } & \text { Qyls } \\ \text { Jwm } & \text { Kk } & \text { Prscq } & \text { Qos } & \text { Qys } \\ \text { KJdd } & \text { Kl } & \text { Prsm } & \text { Qs } & \text { Qyt } \\ \text { KJdg } & \text { Klm } & \text { Prsq } & \text { Qs } & \text { Trf } \\ \text { KJgm } & \text { Kms } & \text { Prsu } & \text { Qt } & \text { Trfl } \\ \text { KJhs } & \text { Kr } & \text { QTs } & \text { Qvof } & \text { Trlm }\end{array}$

$\mathrm{Mz}=$ Mesozoic $(\mathbf{M z}) \quad \mathrm{PP}=$ Pennsylvian $(\mathbb{P}) \quad \mathrm{C}=$ Cambrian $(€)$

$\operatorname{Pr}=$ Proterozoic $(\mathrm{P}) \quad \operatorname{Tr}=$ Triassic $(\mathrm{k})$

Table 7 - Map Units (TAG)

$\begin{array}{lllll}\text { CbkA } & \text { KJlsA } & \text { KrlA } & \text { QaA } & \text { Qvof }{ }_{1} A \\ \text { CcA } & \text { KJosA } & \text { KwcA } & \text { QafA } & \text { Qvof }{ }_{2} A \\ \text { CwA } & \text { KJqdA } & \text { MmA } & \text { QcA } & \text { QvolsA } \\ \text { CzA } & \text { KJspA } & \text { MzuA } & \text { QfA } & \text { QwA } \\ \text { DsA } & \text { KbpA } & \text { PPbsA } & \text { Qf }_{1} A & \text { QyaA } \\ \text { JcA } & \text { KcmA } & \text { PrccA } & \text { Qf }_{2} A & \text { Qya } \\ \text { JcrA } & \text { KcrA } & \text { PrgsqA } & \text { QlsA } & \text { QycA } \\ \text { JdA } & \text { KdhA } & \text { PrlsmA } & \text { QofA } & \text { QyfA } \\ \text { JrrA } & \text { KgmA } & \text { PrqcA } & \text { Qof } A & \text { Qyf } \\ \text { JscA } & \text { KhA } & \text { PrscA } & \text { QolsA } & \text { QylsA } \\ \text { JwmA } & \text { KkA } & \text { PrscqA } & \text { QosA } & \text { QysA } \\ \text { KJddA } & \text { KlA } & \text { PrsmA } & \text { QsA } & \text { QytA } \\ \text { KJdgA } & \text { KlmA } & \text { PrsqA } & \text { Qs }{ }_{1} A & \text { TrfA } \\ \text { KJgmA } & \text { KmsA } & \text { PrsuA } & \text { QtA } & \text { TrflA } \\ \text { KJhsA } & \text { KrA } & \text { QTsA } & \text { QvofA } & \text { TrlmA }\end{array}$

$\mathrm{Mz}=$ Mesozoic $(\mathrm{Mz}) \quad \mathrm{PP}=$ Pennsylvian $(\mathbb{P}) \quad \mathrm{C}=$ Cambrian $(€)$

$\operatorname{Pr}=$ Proterozoic $(\mathrm{E}) \quad \mathrm{Tr}=$ Triassic $(\mathrm{k})$

Points-Point information (structural attitudes) is recorded as coordinate and related information and is described in a point attribute table (.pat) (Table 8). The identities of point types recorded in the P-TAG field of the table are shown in Table 9. The orientation of geologic point data is based upon application of the right-hand rule.

Table 8 - Items, Point Attribute Table (btlrpk_pts.pat) (quantitative data)

ITEM NAME WIDTH OUTPUT TYPE N. DEC

$\begin{array}{llllll}\text { AREA } & 8 & 18 & \text { F } & 3 & \text { Not used }\end{array}$ 


\begin{tabular}{|c|c|c|c|c|}
\hline PERIMETER & 8 & 18 & $\mathrm{~F}$ & Not used \\
\hline BTLRPK_PTS\# & 4 & 5 & $\mathrm{~B}$ & $\begin{array}{l}\text { Internal number assigned by } \\
\text { ARC/INFO }\end{array}$ \\
\hline BTLRPK_PTS-ID & 4 & 5 & $\mathrm{~B}$ & User assigned identification number \\
\hline P-DIP & 3 & 3 & $\mathrm{I}$ & Dip of planar and linear structures \\
\hline P-STRIKE & 3 & 3 & $\mathrm{I}$ & $\begin{array}{l}\text { Azimuth of planar and linear } \\
\text { structures }\end{array}$ \\
\hline P-SYMB & 3 & 3 & $\mathrm{I}$ & $\begin{array}{l}\text { Calls point-type from marker set } \\
\text { geoSCAMP2.mrk }\end{array}$ \\
\hline P-TAG & 25 & 25 & $\mathrm{C}$ & Links points to data table points.rel \\
\hline P-UNIQUE & 200 & 200 & $\mathrm{C}$ & $\begin{array}{l}\text { Attributes of specific points within a } \\
\text { point type }\end{array}$ \\
\hline P-AGECON & 50 & 50 & $\mathrm{C}$ & $\begin{array}{l}\text { Confidence of geologic age } \\
\text { assignment }\end{array}$ \\
\hline P-SOURCE & 200 & 200 & $\mathrm{C}$ & Source of compiled data \\
\hline P-AGE & 100 & 100 & $\mathrm{C}$ & $\begin{array}{l}\text { Geologic age of point feature if } \\
\text { determined }\end{array}$ \\
\hline P-PLUNGE & 3 & 3 & $\mathrm{I}$ & Plunge of linear elements \\
\hline P-DIPDIR & 3 & 3 & I & $\begin{array}{l}\text { Azimuthal direction of dip (assuming } \\
\text { the right-hand rule) }\end{array}$ \\
\hline
\end{tabular}

Table 9 - Point Types (quantitative) (P-TAG) and a brief summary of the corresponding parsed description in P-EXP in points.rel

FN13 Foliation, primary igneous, inclined

FN31 Foliation, layered cataclastic rock, inclined

FN42 Foliation, metamorphic, inclined

FN43 Foliation, metamorphic, vertical

L14 Lineation, crushed and streaked mineral grains, inclined

L22 Lineation, metamorphic, aligned mineral grains

L37 Lineation, metamorphic, minor fold axes

\section{REFERENCES}

Environmental Systems Research Institute, Inc, 1991, ARC/INFO command references 6.0: Proprietary software manual

Matti, J.C., Miller, F.K., Powell, R.E., Kennedy, S.A., and Cossette, P.M., 1998a, Geologic-polygon attributes for digital geologic map databases produced by the Southern California Areal Mapping Project (SCAMP), Version 1.0: U.S.Geological Survey Open-File Report 97-860

Matti, J.C., Powell, R.E., Miller, F.K., Kennedy, S.A., Ruppert, K.R., Morton, G.L., and Cossette, P.M., 1998b, Geologic-line attributes for digital geologic map databases produced by the Southern California Areal Mapping Project (SCAMP), Version 1.0: U.S.Geological Survey Open-File Report 97-861 
Matti, J.C., Miller, F.K., Powell, R.E., Kennedy, S.A., Bunyapanasarn, T.P., Koukladas, Catherine, Hauser, R.M., and Cossette, P.M., 1998c, Geologic-point attributes for digital geologic map databases produced by the Southern California Areal Mapping Project (SCAMP), Version 1.0: U.S.Geological Survey Open-File Report 97-859 